\title{
A Comprehensive Procedure for the Partial Discharge Measurements \& Power Frequency Withstand Test on GIS in Transmission Substations
}

\author{
Shaik Mohammad Tayyab, K. Chandra Sekhar
}

\begin{abstract}
The Transmission part of the power sector is very much important as it deals with the huge losses of the complete power sector. Transmission substations play a key role in the power transmission process since the power generation at the power plants to the final stage at the consumer end utilization. The utmost care should be taken to protect these transmission substations as same as the care is taken to reduce the losses. The substation needs to be protected from blackouts which is the big problem of substations. For this, the substation high voltage equipment's like GIS \& Power Transformers are to be properly installed \& energized according to the standards \& care is taken for its maintenance. So, during the commissioning process which is after installation \& before energization, there are different tests which are performed on high voltage equipment's, especially the Gas Insulated Switchgear, in which the High Voltage \& Partial discharge has huge impact as the ageing and the life time of GIS can be easily assessed \& the GIS can be saved from the damage, tripping and the blackout of a substation. The procedure of the high voltage test and the partial discharge tests are clearly explained in this paper.
\end{abstract}

Keywords: Partial Discharge, High Voltage, Fiber Optic, Transmission Substations, GIS- Gas Insulated Switchgears.

\section{INTRODUCTION}

Many equipment's are present in the substation in which the high voltage equipment's like Gas Insulated Switchgears \& Power Transformers' constitutes for the major part. The equipment's are tested number of times from the time it is manufactured in the factory to the final energization in the substation. Gas Insulated Switchgear is unique high voltage equipment which has wide uses in the substations. It comprises of all the bay equipment's like Circuit Breaker, Earth Switch, Disconnector Switch, Current Transformer, Voltage Transformer, Cable Chamber which are compacted \& enclosed in SF6 gas. GIS compact nature reduces the space of substations and hence can be constructed in any part of the

Manuscript received on November 05, 2021.

Revised Manuscript received on November 09, 2021.

Manuscript published on November 30, 2021.

* Correspondence Author

Mr. Shaik Mohammad Tayyab*, Dept. of Electrical \& Electronics Engineering, Acharya Nagarjuna University, Guntur, India. Email: tayyab2991@gmail.com

Prof. K. Chandra Sekhar, Dept. of Electrical \& Electronics Engineering, R.V.R \& J.C College of Engineering, Guntur, India. Email: cskoritala@gmail.com

(c) The Authors. Published by Blue Eyes Intelligence Engineering and Sciences Publication (BEIESP). This is an open access article under the CC BY-NC-ND license (http://creativecommons.org/licenses/by-nc-nd/4.0/) city despite of any reasons.

\section{DEFINITIONS}

\section{A. Power Frequency Withstand Voltage}

The r.m.s value in a sinusoidal power frequency voltage which an equipment can withstand when applied for different test performance under specific time which is usually for a minute.

\section{B. Power Frequency Withstand Voltage Test}

Power frequency withstand voltage test which is also known as high voltage test on the Gas Insulated Switchgear is performed so as to ensure the dielectric strength of the GIS, confirm that the equipment can be energized and is capable to withstand its limit of high voltage upon energization.

\section{Partial Discharge}

Partial discharge is defined as the partial sparking or partial bridging in the insulation medium between the two electrodes or conductors. It doesn't have any impact in the initial stages but lead to the complete breakdown in the future if it's not identified \& resolved in the initial stage.

\section{PREPARATION STEPS FOR HV TEST}

The following are the

- Before test preparation, GIS is confirmed to be in de-energization state and Circuit breaker, disconnectors are isolated (Open position) and earthing switches are closed to ground.

- $\quad$ SF6 gas is filled in cable sealing end chamber \& then discharged (degassed) from the chamber.

- $\quad$ Remove the top cover of the cable sealing end chamber.

- The removable link should be dismantled from GIS conductors to avoid applying voltage at cable side.

- The GIS auxiliary conductor to perform the HV test is assembled with test bushing module.

- $\quad$ Test bushing is installed with utmost care on the cable sealing end chamber.

- This installation is usually done under the supervisor of the GIS manufacturer.

- All the covers are closed for vacuuming and SF6 gas is filled up to the rated operating pressure.

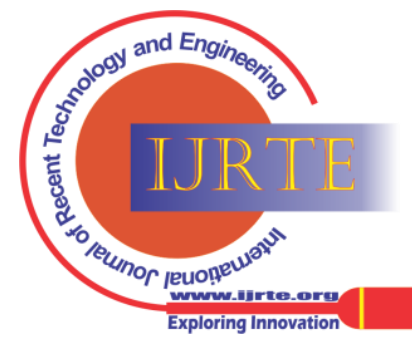



on GIS in Transmission Substations

- HV Test is performed and the reverse procedure is followed for the de-assembly work

The below figure represents the assembly of HV Test bushing on the Gas Insulated Switchgear

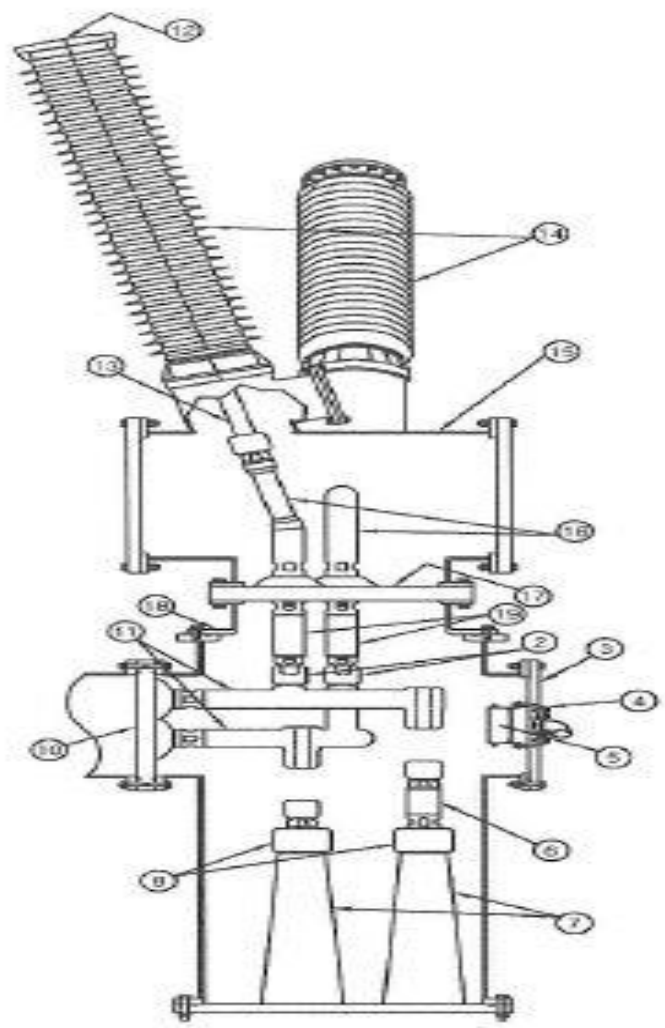

Fig - 1: HV test bushing assembly on GIS

The various parts are al below:

1. Cover of cable chamber

2. Tulip contactor

3. Cover for inspection hole

4. Rupture disc device assembly

5. Case of absorbent

6. Connection conductor

7. Cable cone

8. Shield for cable sealing end

9. Removable link

10. Gas tight barrier insulator

11. Conductors

12. Terminal plate for HV applying

13. Conductor of bushing interior

14. Bushing for HV test

15. Enclosure for bushing assembly

16. Conductor

17. Gas tight barrier insulator

18. Flange to connect to cable chamber

19. Conductors to connect to cable chamber

\section{HV / POWER FREQUENCY WITHSTAND TEST}

The HV Test is performed as below:

$\mathrm{HV}$ test is a crucial test that is performed on the Gas Insulated Switchgear. After the all requirements are fulfilled, HV test is performed as below:

- All test objects are filled with SF6 gas up to the rated operating pressure.
- Moisture content \& gas purity test is performed.

- Mechanical operation test for Disconnecting Switches, Earthing Switches, circuit breakers are performed.

- Secondary windings of all CT's are short - circuited and grounded.

- $\quad$ During the performance of test, all the HV cables are disconnected.

- $\quad$ PT for the bus shall be de-energized or dismantled.

- Test voltage is applied from HV test set to GIS via Gas to air bushing connected to GIS with the wire covered by corona free shield.

- $\quad$ All the circuit breakers \& disconnecting switches are in closed position \& Earthing Switches in Open position.

- To verify the circuit condition, Insulation resistance test at 5kVDC is performed.

- In case of R phase injection, Y \& B phases are grounded together.

- In case of Y phase injection, R \& B phases are grounded together.

- $\quad$ In case of B phase injection, Y \& R phases are grounded together.

- The same is repeated including VT's also to ensure the dielectric strength of VT's.

The circuit for the HV test can be represented as below:

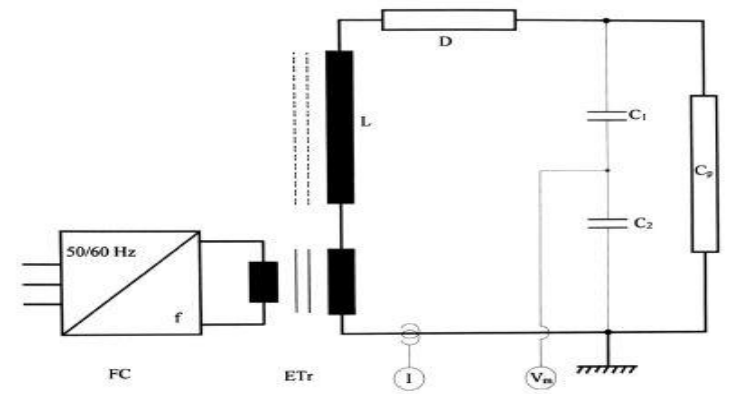

Fig - 2: Circuit for HV test

Where,

- $\quad \mathrm{FC}=$ Frequency Converter

- $\quad \mathrm{ETr}=$ Exciter Transformer

- $\quad \mathrm{L}=$ Reactor Unit

- $\quad \mathrm{D}=$ Damping Resistor

- $\quad$ C1 = HV Capacitor

- $\quad$ C2 = LV Capacitor

- $\quad \mathrm{Cp}=$ Device under test

- $\quad$ I = Current measurement

The applying voltage levels for the $\mathrm{HV}$ test is mentioned as in below table according to the IEC standard

Table- I: Site test voltages for $\mathrm{HV}$ test as per IEC

\begin{tabular}{|c|c|c|}
\hline No. & $\begin{array}{c}\text { Rated voltage } \\
\text { for GIS }\left(\mathrm{U}_{\mathrm{r}}\right) \\
\mathrm{kV}\end{array}$ & $\begin{array}{c}\text { On-site short duration power } \\
\text { frequency withstand test }\left(\mathrm{U}_{\mathrm{ds}}\right) 1 \mathrm{~min} \\
\mathrm{kV}\end{array}$ \\
\hline 1 & 72.5 & 120 \\
\hline 2 & 100 & 165 \\
\hline 3 & 123 & 200 \\
\hline 4 & 145 & 235 \\
\hline 5 & 170 & 270 \\
\hline 6 & 245 & 380 \\
\hline 7 & 300 & 380 \\
\hline 8 & 362 & 425 \\
\hline 9 & 420 & 515 \\
\hline 10 & 550 & 560 \\
\hline
\end{tabular}

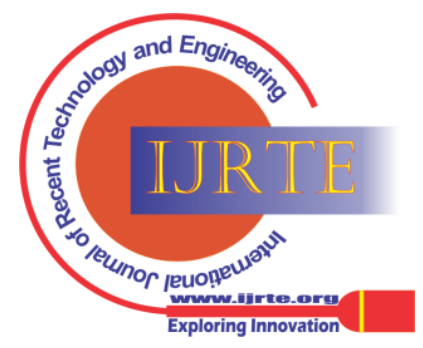


The graphical representation for the HV test can be as shown in below

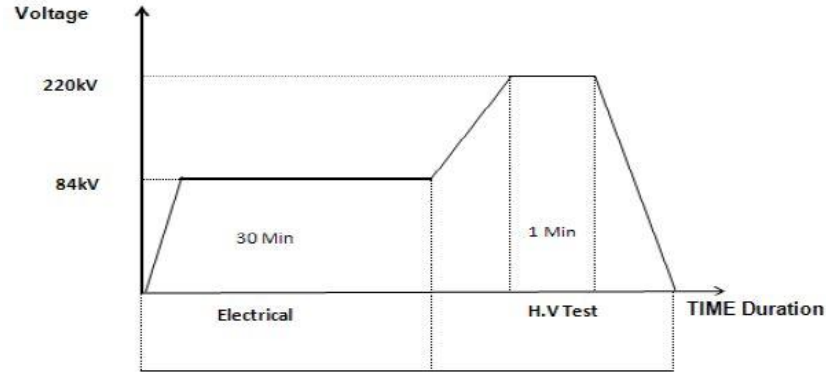

Fig - 3: Graphical representation for typical 110kV GIS HV test

\section{PARTIAL DISCHARGE MEASUREMENTS / TEST}

The circuit representation for partial discharge test is same as the power frequency withstand test/ HV test circuit. At first, the applied voltage is raised to power frequency withstand voltage and maintained for 60 seconds and the voltage is decreased to PD test voltage without interruption \& the partial discharges are measured. The test voltage values are mentioned in below table

Table- II: Site test voltages for $P D$ as per IEC standard

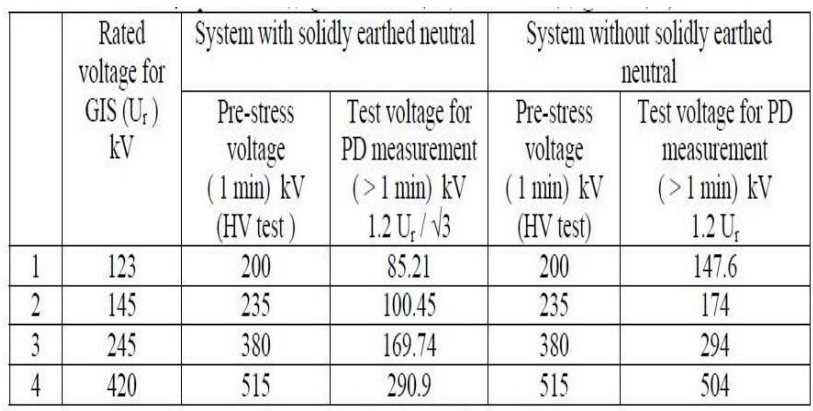

The graphical representation for the partial discharge test are represented as per below

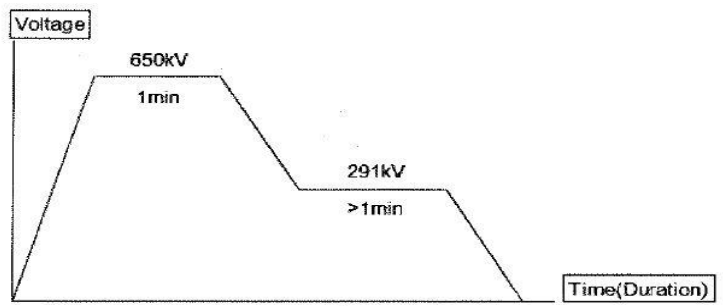

Fig - 4: Graphical representation for typical $380 \mathrm{kV}$ PD

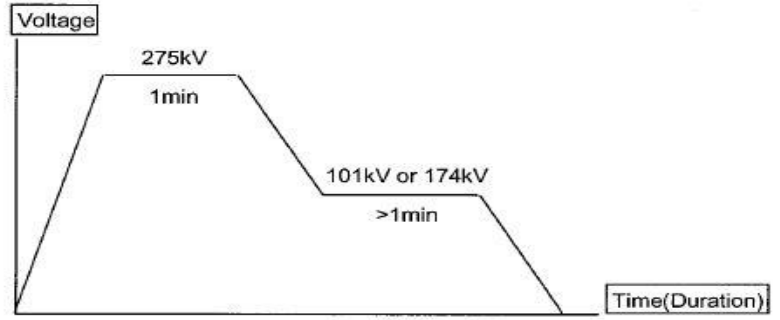

Fig - 5: Graphical representation for typical $110 \mathrm{kV}$ PD

\section{EXPERIMENTAL RESULTS}

Voltage Application during test:

Applied voltage:

• 85 kV Duration: 5 minutes

- 150 kV Duration:3 minutes

- 235 kV Duration:1 minutes

- $\quad$ Test voltage will be applied for various voltages \& timings as mentioned above between each conductor and ground enclosure, keeping the other two-phase ground.

- Voltage Transformer will be excluded from the test.

- Test voltage will be applied at the Test Bushing of each phase under test.

Insulation Test: 5 kV DC Megger between Ph - Gnd for 1 min (Before HV Test)

\begin{tabular}{|c|c|c|}
\hline PHASE & $\begin{array}{c}\text { INSULATION } \\
\text { RESISTANCE }\end{array}$ & REMARKS \\
\hline R-GND & $\mathbf{3 . 4 5} \mathbf{T \Omega}$ & Y \& B GROUNDED \\
\hline Y-GND & $\mathbf{3 . 2 3} \mathbf{T} \boldsymbol{\Omega}$ & R \& B GROUNDED \\
\hline B-GND & $\mathbf{2 . 7 0} \mathbf{T} \boldsymbol{\Omega}$ & R \&Y GROUNDED \\
\hline
\end{tabular}

Criteria: > $10 \mathrm{G} \Omega$

Applied voltage $85 \mathrm{kV}$ :

\begin{tabular}{|c|c|c|c|}
\hline Phase & $\mathbf{R}$ & $\mathbf{Y}$ & B \\
\hline Ambient Temp. ${ }^{\circ} \mathrm{C}$ & 25 & 25 & 25 \\
\hline $\begin{array}{c}\text { Resonant frequency } \\
\text { (HZ) }\end{array}$ & $102.32 \mathrm{~Hz}$ & $101.73 \mathrm{~Hz}$ & $102.91 \mathrm{~Hz}$ \\
\hline Voltage applied (KV) & $85 \mathrm{kV}$ & $85 \mathrm{kV}$ & $85 \mathrm{kV}$ \\
\hline $\begin{array}{l}\text { Applied voltage } \\
\text { duration (Min) }\end{array}$ & $5 \mathrm{~min}$ & $5 \mathrm{~min}$ & $5 \mathrm{~min}$ \\
\hline Charging current (A) & $0.5 \mathrm{~A}$ & $0.5 \mathrm{~A}$ & $0.5 \mathrm{~A}$ \\
\hline
\end{tabular}

CRITERIA: No disruptive discharge occurs during the high voltage test .

Applied voltage $150 \mathrm{kV}$ :

\begin{tabular}{|c|c|c|c|}
\hline Phase & R & Y & B \\
\hline Ambient Temp. ${ }^{\circ} \mathrm{C}$ & 25 & 25 & 25 \\
\hline $\begin{array}{c}\text { Resonant frequency } \\
\text { (HZ) }\end{array}$ & $102.32 \mathrm{~Hz}$ & $101.73 \mathrm{~Hz}$ & $102.91 \mathrm{~Hz}$ \\
\hline \begin{tabular}{c} 
Voltage applied (KV) \\
\hline $\begin{array}{c}\text { Applied voltage } \\
\text { duration (Min) }\end{array}$
\end{tabular} & $\mathbf{1 5 0} \mathrm{kV}$ & $150 \mathrm{mV}$ & $150 \mathrm{kV}$ \\
\hline Charging current (A) & $\mathbf{0 . 9} \mathrm{A}$ & $3 \mathrm{~min}$ & $3 \mathrm{~min}$ \\
\hline
\end{tabular}

CRITERIA: No disruptive discharge occurs during the high voltage test.

Applied voltage 235 kV

\begin{tabular}{|c|c|c|c|}
\hline Phase & R & Y & B \\
\hline Ambient Temp. ${ }^{\circ} \mathrm{C}$ & 25 & 25 & 25 \\
\hline $\begin{array}{c}\text { Resonant frequency } \\
\text { (HZ) }\end{array}$ & $102.32 \mathrm{~Hz}$ & $101.73 \mathrm{~Hz}$ & $102.9 \mathrm{~Hz}$ \\
\hline $\begin{array}{c}\text { Voltage applied (KV) } \\
\text { Applied voltage duration } \\
\text { (Min) }\end{array}$ & $235 \mathrm{kV}$ & $235 \mathrm{kV}$ & $235 \mathrm{kV}$ \\
\hline Charging current (A) & $1.4 \mathrm{~A}$ & $1.4 \mathrm{~min}$ & $1 \mathrm{~min}$ \\
\hline
\end{tabular}

CRITERIA: No disruptive discharge occurs during the High voltage test.

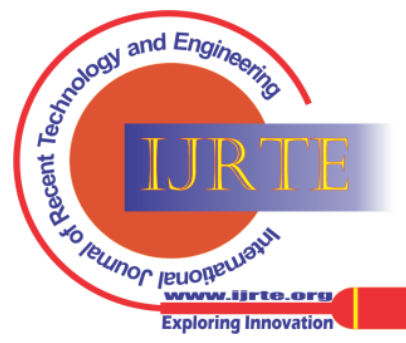


A Comprehensive Procedure for the Partial Discharge Measurements \& Power Frequency Withstand Test on GIS in Transmission Substations

Insulation Test: 5 kV DC Megger between Ph - Gnd for 1 min (After HV Test)

\begin{tabular}{|c|c|c|}
\hline PHASE & $\begin{array}{l}\text { INSULATION } \\
\text { RESISTANCE }\end{array}$ & REMARKS \\
\hline R-GND & $2.27 \mathrm{~T} \Omega$ & Y \& B GROUNDED \\
\hline Y-GND & $\mathbf{2 . 3 8} \mathbf{T} \Omega$ & R \& B GROUNDED \\
\hline B-GND & $\mathbf{1 0 . 0} \mathbf{T} \Omega$ & R \&Y GROUNDED \\
\hline
\end{tabular}

Criteria: > $10 \mathrm{G}$ ohms

Partial Discharge event analysis on the R-Phase of $110 \mathrm{kV}$ GIS is as below:

\begin{tabular}{|c|c|c|c|}
\hline No. & Channel & Q-max & PD Analysis \\
\hline 1 & E06-BB & $0.18 \mathrm{pC}$ & Normal \\
\hline 2 & E06-VT & $0.20 \mathrm{pC}$ & Normal \\
\hline 3 & E04-BB & $0.18 \mathrm{pC}$ & Normal \\
\hline 4 & E04-VT & $0.18 \mathrm{pC}$ & Normal \\
\hline 5 & E02-BB & $0.18 \mathrm{pC}$ & Normal \\
\hline 6 & E02-VT & $0.18 \mathrm{pC}$ & Normal \\
\hline 7 & E130-BB & $0.18 \mathrm{pC}$ & Normal \\
\hline 8 & E230-BB & $0.18 \mathrm{pC}$ & Normal \\
\hline 9 & E220-BB1 & $0.18 \mathrm{pC}$ & Normal \\
\hline 10 & E220-BB2 & $0.18 \mathrm{pC}$ & Normal \\
\hline 11 & E01-BB & $0.18 \mathrm{pC}$ & Normal \\
\hline 12 & E01-VT & $0.18 \mathrm{pC}$ & Normal \\
\hline 13 & E03-BB & $0.18 \mathrm{pC}$ & Normal \\
\hline 14 & E03-VT & $0.18 \mathrm{pC}$ & Normal \\
\hline 15 & E05-VT & $0.18 \mathrm{pC}$ & Normal \\
\hline 16 & E05-BB & $0.18 \mathrm{pC}$ & Normal \\
\hline
\end{tabular}

Partial Discharge event analysis on the Y-Phase of $110 \mathrm{kV}$ GIS is as below:

\begin{tabular}{|c|c|c|c|}
\hline No. & Channel & Q-max & PD Analysis \\
\hline 1 & E06-BB & $0.20 \mathrm{pC}$ & Normal \\
\hline 2 & E06-VT & $0.18 \mathrm{pC}$ & Normal \\
\hline 3 & E04-BB & $0.18 \mathrm{pC}$ & Normal \\
\hline 4 & E04-VT & $0.18 \mathrm{pC}$ & Normal \\
\hline 5 & E02-BB & $0.18 \mathrm{pC}$ & Normal \\
\hline 6 & E02-VT & $0.18 \mathrm{pC}$ & Normal \\
\hline 7 & E130-BB & $0.18 \mathrm{pC}$ & Normal \\
\hline 8 & E230-BB & $0.18 \mathrm{pC}$ & Normal \\
\hline 9 & E220-BB1 & $0.18 \mathrm{pC}$ & Normal \\
\hline 10 & E220-BB2 & $0.18 \mathrm{pC}$ & Normal \\
\hline 11 & E01-BB & $0.18 \mathrm{pC}$ & Normal \\
\hline 12 & E01-VT & $0.18 \mathrm{pC}$ & Normal \\
\hline 13 & E03-BB & $0.18 \mathrm{pC}$ & Normal \\
\hline 14 & E03-VT & $0.18 \mathrm{pC}$ & Normal \\
\hline 15 & E05-BB & $0.18 \mathrm{pC}$ & Normal \\
\hline 16 & E05-VT & $0.18 \mathrm{pC}$ & Normal \\
\hline
\end{tabular}

Partial Discharge event analysis on the B- Phase of $110 \mathrm{kV}$ GIS is as below:

\begin{tabular}{|c|c|c|c|}
\hline No. & Channel & Q-max & PD Analysis \\
\hline 1 & E06-BB & $0.18 \mathrm{pC}$ & Normal \\
\hline 2 & E06-VT & $0.18 \mathrm{pC}$ & Normal \\
\hline 3 & E04-BB & $0.18 \mathrm{pC}$ & Normal \\
\hline 4 & E04-VT & $0.18 \mathrm{pC}$ & Normal \\
\hline 5 & E02-BB & $0.18 \mathrm{pC}$ & Normal \\
\hline 6 & E02-VT & $0.18 \mathrm{pC}$ & Normal \\
\hline 7 & E130-BB & $0.18 \mathrm{pC}$ & Normal \\
\hline 8 & E230-BB & $0.18 \mathrm{pC}$ & Normal \\
\hline 9 & E220-BB1 & $0.22 \mathrm{pC}$ & Normal \\
\hline 10 & E220-BB2 & $0.18 \mathrm{pC}$ & Normal \\
\hline 11 & E01-BB & $0.18 \mathrm{pC}$ & Normal \\
\hline 12 & E01-VT & $0.18 \mathrm{pC}$ & Normal \\
\hline 13 & E03-BB & $0.18 \mathrm{pC}$ & Normal \\
\hline 14 & E03-VT & $0.18 \mathrm{pC}$ & Normal \\
\hline 15 & E05-BB & $0.18 \mathrm{pC}$ & Normal \\
\hline 16 & E05-VT & $0.18 \mathrm{pC}$ & Normal \\
\hline
\end{tabular}

\section{RESULT AND DISCUSSION}

The experimental results are listed above, for the HV test the results are in the range of criteria while the partial discharge measurement (Charge $-\mathrm{Q}$ ) value which will be in pico coloumbs is also under the limit of less than $5 \mathrm{pC}$ which is the criterion.

\section{CONCLUSION}

The procedures for the power frequency withstand test \& measurement of partial discharges are explained clearly in this paper with the practical experimental results.

\section{ACKNOWLEDGMENT}

This paper work is based on the research on the Transmission Substations to increase the life of the Gas Insulated Switchgears \& also to prevent the huge equipment damage or loss by tracing out the possible cause of damage at the earliest before occurrence.

\section{REFERENCES}

1. J. S. Pearson, et al., "Partial Discharge Diagnostics for Gas-Insulated Substations," IEEE Trans. On Diel. and El. Ins., vol. 2, no. 5, 1995, pp. 893-905.

2. A. Bargigia, W. Kultonowicz, A Pigini, "Detection of Partial Discharges in GIS," IEEE Trans.on Power and Delivery, vol. 7, no. 3, July 1992, pp $1239-1246$.

3. H D. Schlemper, R. Kurrer, K. Feser, "Sensitivity of On-Site Partial Discharge Detection in GIS," Proc. of the 8th ISH, Yokohama, 1993, paper 66.04.

4. B.F. Hampton, et. al, "Experience and Progress with UHF Diagnostic in GIS," CIGRE Sess., Paris, 1992, Paper 15/23-03.

5. A G Sellars, O. Farish, and B F Hampton, "Assessing the Risk of Failure due to Particle Contamination of GIS using the UHF Technique", IEEE Trans Dielectrics and Electrical Insulation, Vol 1, No 2, pp 323-331, 1994.

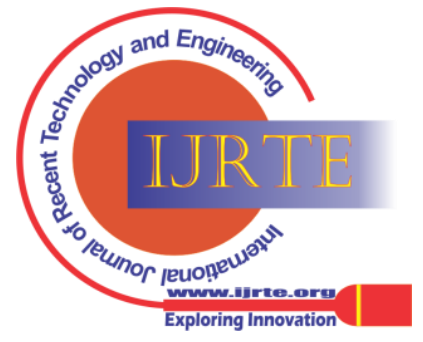




\section{AUTHOR PROFILE}

Mr. Shaik Mohammad Tayyab, a research scholar in the dept. of Electrical \& Electronics Engineering, Acharya Nagarjuna University. Having completed B.Tech in the year 2014 \& M.Tech - Power Systems Engineering in the year 2016, currently pursuing Ph.D. in the field of substations especially on Gas Insulated Switchgears. Areas of interests include Smart grids, Substation Automation Systems, R\&D in GIS substations, AI \& ANN techniques for the electrical power quality improvement

Dr. K. Chandra Sekhar, currently working as Professor \& Head for the dept. of Electrical \& Electronics Engineering in R.V.R \& J.C. College of Engineering, Guntur. He has graduated in the year 1991\& has done Masters in the year 1994 \& received doctorate - Ph.D. in the year 2008. He has vast experience in the field of R\&D and teaching for $24+$ years. \& published several international journals \& guided many scholars for doing the research works.

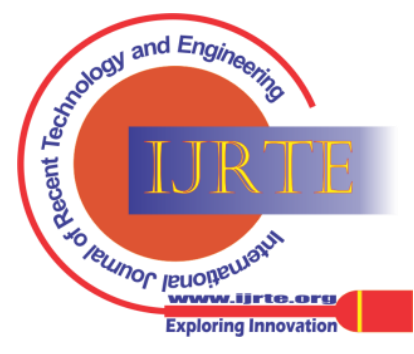

